\title{
Assessment of relationships among and within Helichrysum Mill. (Asteraceae) species by using ISSR markers and morphological traits
}

\section{Narjes Azizi', Masoud Sheidai ${ }^{2}$ (1) , Valiollah Mozaffarian³ ${ }^{3}$ Mitra Arman ${ }^{4}$ \& Zahra Noormohammadi ${ }^{5}$}

Key words: Helichrysum, ISSR Marker, Morphology, Population, Iran.

Ključne besede: Helichrysum, ISSR markerji, morfologija, populacija, Iran.
Received: 18. 4. 2018

Revision received: 4. 12. 2018

Accepted: 19. 12. 2018

\begin{abstract}
This study conducted to determine relationship among and within Iranian Helichrysum species (Asteraceae). In this study based on ISSR markers, the highest percentage of ISSR loci polymorphism (54.7\%) occurred in H. armenium. The highest gene diversity over loci (1.224), Shannon's Information Index (0.224\%) and Expected Heterozygosity $(0.142 \%)$ occurred in $H$. armenium (0.18) and the lowest of these parameters $(0 \%)$ were observed in $H$. araxinum, $H$. graveolens, $H$. persicum and $H$. psychrophilum. The highest genetic similarity occurred between $H$. armenium and H. rubicundum (0.989), while the lowest was between $H$. polyphyllum and $H$. graveolens (0.213). The analysis of molecular variance (AMOVA), showed significant genetic variation among $(24 \%)$ and within $(76 \%)$ species. In morphological analysis traits such as indumentum, resting bud, achene length, achenial papillae, dimension of receptacle and form and apex of phyllaries were main diagnostic features. Results obtained from the morphological cluster were greatly consistent with the molecular data, to elucidating taxonomic relationships, as well as both attributed the higher diversity in $H$. armenium and $H$. rubicundum in comparison with other species and also indicated that $H$. persicum is a member of $H$. oocephalum species. Totally we confirmed the presence of 18 species in Iran.

Izvleček

V raziskavi smo obravnavali taksonomske razlike med vrstami in znotraj vrst rodu Helichrysum (Asteraceae) v Iranu. V raziskavi na podlagi ISSR markerjev smo pokazali, da je bil največji delež ISSR polimorfnih lokusov $(54,7 \%)$ v populacijah $H$. armenium. Največja genska raznolikost lokusov $(1,224)$, Shannonov indeks $(0,224 \%)$ in pričakovana heterozigotnost $(0,142 \%)$ je bila pri vrsti $H$. armenium $(0,18)$ in najmanjši $(0 \%)$ pri vrstah $H$. araxinum, $H$. graveolens, $H$. persicum in $H$. psychrophilum. Največjo genetsko podobnost smo opazili med vrstama $H$. armenium in $H$. rubicundum $(0,989)$, medtem ko je bila najmanjša med vrstama $H$. polyphyllum in $H$. graveolens $(0,213)$. Analiza molekularne variance (AMOVA) je pokazala značilno genetsko variabilnost med $(24 \%)$ vrstami in znotraj $(76 \%)$ vrst. V morfološki analizi tega rodu so bili najpomembnejši diagnostični znaki dlakavost, speči brsti, dolžina rožke, papile na rožki, velikost socvetišča, oblika in vrh ovojkovih listov. Rezultati klastrske analize morfoloških znakov so bili v skladu z molekularnimi analizami. Obe analizi sta pokazali veliko raznolikost vrst $H$. armenium in $H$. rubicundum v primerjavi z ostalimi in da vrsta H. persicum v bistvu pripada vrsti H. oocephalum. Skupaj smo v Iranu potrdili 18 vrst iz rodu Helichrysum.
\end{abstract}

\footnotetext{
1 Forest and Rangeland Department, Khorasan Razavi Agricultural and Natural Resources Research and Education Center. AREEO. Mashhad, Iran. E-mail: n.azizi@areeo.ac.ir

2 Faculty of Biologia, Shahid Beheshti University, Tehran, Iran.

3 Research institute of Forests and Rangelands. AREEO, Tehran, Iran.

4 Department of biology, Payamenoor University, P. O. Box 19395-3697, Tehran, Iran.

5 Department of Biology School of Science, Tehran, Science and Research Branch, Islamic Azad University, Tehran, Iran.
} 


\section{Introduction}

Helichrysum Mill (Gnaphalieae) is one of the largest genera in Asteraceae with about 600 species in the world (Anderberg 1991, Bayer et al. 2007). It includes a great diversity of life forms, from annual plants to trees, although most of the species are sub shrubs or shrubs. The genus is characterized as having homogamous or heterogamous capitula, generally with hermaphrodite florets outnumbering female florets; phyllaries with a fenestrated stereome; a flat, generally smooth or toothed receptacle; cypselae glabrous or covered with duplex or twin hairs; and a pappus that is monomorphic and usually uniseriate, consists of several scabrid to plumose bristles, and is free at the base (Hilliard \& Burtt 1981). Even though the highest biodiversity of Helichrysum is in the African continent and Madagascar (Anderberg 1991), but also -45 of them distributed in the Mediterranean, European, western Asian, and central Asian, that are morphologically characterized as having the following traits: homogamous or heterogamous capitula, with hermaphroditic flowers outnumbering the pistillate ones; phyllaries with a fenestrated stereome; smooth or alveolate receptacle; cypselae glabrous or with duplex hairs; monomorphic uniseriate pappus, consisting of several free scabrid bristles, with patent cilia at the base.

According to Flora Iranica (Georgiadou et al. 1980) 19 species are distributed in Iran, that seven species of them are endemic.

Helichrysum is a large and taxonomically difficult genus (Galbany et al. 2009). Because of extreme morphological variation, plant identification is often obscured by high inter and intra -population variation (Puglia et al. 2016). Thus evaluation of variation within taxa and populations is necessary, and it is one of the main aims of the present study.

In this genus the relationships and infrageneric classification have remained largely unresolved. Morphological approach provided essential tools for estimating the plasticity of the species within this genus (Galbany-Casal et al. 2006a, Salmeri et al. 2014). Some studies concerning molecular markers have provided insights into phylogenetic relationships, by using nrDNA ITS and chloroplast psbA-trnH sequences and DNA ndh F sequence variation (Galbany et al. 2004, 2009, 2014, Smissen et al. 2011) and amplified fragment length polymorphism (W. Sabetta 2006, Scialabba et al. 2008, Galbany et al. 2012, 2014). Other type of DNA markers which are used for genetic analysis in Helichrysum species include, express sequence tag-polymerase chain reaction (ETS-PCR) that is used to evaluate phylogenetic relationships in Helichrysum and related genera (Galbany et al. 2014).
In the present study, we used ISSR marker that has not been reported with Helichrysum except in three Helichrysum species in Iran and seven species in Sicilian Helichrysum (Azizi et al. 2014, Taban et al. 2015, Puglia et al. 2016). The main aims of this study were (1) to investigate the genetic relationships within Iranian Helichrysum using molecular data, (2) to identify diagnostic morphological traits which are useful for the classification of genera, and (3) to assess the relationships among and within Helichrysum species.

\section{Material methods}

\section{Plant material}

In this work, samples of 101 populations of 19 species of Helichrysum genus were studied. In morphological section, 87 populations contain: 1 population ( 2 individuals) of $H$. araxinum Takht. ex Kirpt., 18 populations (49 individuals) of $H$. armenium DC., 3 populations (8 individuals) of $H$. artemisioides Boiss \& Hausskn., 2 populations (7 individuals) of $H$. aucheri Boiss., 3 populations (8 individuals) of $H$. davisianum Rech. f., 3 populations (8 individuals) of $H$. glanduliferum SchultzBip., 4 populations (10 individuals) of $H$. globiferum Boiss., 3 populations (6 individuals) of $H$. graveolens (M. B.) Sweet., 5 populations (23 individuals) of H. leucocephalum Boiss.,5 populations (14 individuals) of $H$. makranicum (Rech. F. \& Esfand.) Rech. f., 3 populations (9 individuals) of $H$. oligocephalum DC., 7 populations (18 individuals) of $H$. oocephalum Boiss., 3 populations (8 individuals) of $H$. pallasii (Spreng.) Ledeb.,1 populations ( 2 individuals) of $H$. persicum Ghahremani \& Noori, 3 populations (8 individuals) of $H$. plicatum DC., 1 populations (3 individuals) of $H$. polyphyllulm Ledeb., 5 populations (13 individuals) of $H$. pseudoplicatum Nab., 3 populations (9 individuals) of $H$. psychrophilum Boiss., 14 populations (44 individuals) of $H$. rubicundum (C. Koch.) Bornm.

The localities in which these were collected are detailed in Table 1.66 populations were collected by us from different parts of Iran between 2010-2012 and are kept in the Herbarium Shahid Beheshti University (HSBU) and 34 populations are based on specimens from Research institute of forests and rangelands (TARI) herbarium.

\section{Morphometric analysis}

Based on material and literature data, 36 morphological traits were investigated for 249 individuals of 87 populations. Of the traits incorporated in the analysis, 
28 were quantitative and 8 were qualitative (Table 3), totally only eight of them corresponded to vegetative features and the remaining traits being concerned with the synflorescence, capitula or florets. Indumentum, involucral bracts, florets and pappus were examined under a Zeiss Stemi DV4 binocular stereoscopic microscope. For the quantitative traits, the mean of measurements per specimen was used in the analyses. As well as these traits were scored at population level for the joint populations both used in molecular and morphological analyses, (the mean of three measurements per specimen was used in the analyses). Measurements were taken with a precision of $0.1 \mathrm{~mm}$. The quantitative morphological traits were divided in to discrete groups and along with qualitative traits were coded as binary or multistate traits.

UPGMA (Unweighted Paired Group using Average mean), NJ, WPGMA clustering methods with 100 times bootstrapping as well as principal components analysis (PCA), principal coordinate analysis ( $\mathrm{PCoA})$ and multidimensional scaling (MDS) were performed to group the plants specimens based on morphological traits. The Euclidean distance was used for clustering methods. Cophenetic correlation was determined to check the fit of dendrograms to the original distance matrix (Podani 2000). Data analyses were performed by using PAST ver. 2.17 (Hamer et al. 2012).

\section{ISSR Analyses}

A total, 64 populations of 18 species (Table 1) were used for DNA extraction by using CTAB-activated charcoal protocol (Križman et al. 2006). We used 2-3 randomly collected plant specimens for any population. ISSR assay DNA was extracted from silica-gel dried leaves collected in the field or from herbarium material.

The extraction procedure was based on activated charcoal and Polyvenyl Pyrrolidone (PVP) for binding of polyphenolics during extraction and on mild extraction and precipitation conditions. This promoted high-molecular weight DNA isolation without interfering contaminants. Quality of extracted DNA was examined by running on $0.8 \%$ agarose gel.

The ISSR bands obtained were treated as binary characters and coded accordingly (presence $=1$, absence $=$ 0 ). Genetic diversity parameters were determined in each species. These parameters were percentage of allelic polymorphism, allele diversity (Weising 2005), Nei's gene diversity $(H)$, Shannon information index $(I)$ (Weising 2005, Freeland et al. 2011), number of effective alleles and percentage of polymorphism. The genetic divergence of the studied populations was checked by principal coordinate analysis provided and after 999 permutations.
Model-based clustering as performed by STRUCTURE software ver. 2.3 (Pritchard et al. 2000), was carried out to group the studied populations based on genetic affinity. This program was also used to reveal the genetic admixture of the studied populations.

AMOVA (Analysis of molecular variance) test (with 1000 permutations) as performed in GenAlex 6.4 (Meirmans \& Van Tienderen, 2004), was used to show the molecular difference among the studied populations.

\section{Results}

\section{Morphological comparison}

In order to define relationship among 19 Helichrysum species based on comparison of morphological features, 36 morphological traits were evaluated. Based on the Euclidian distance, a taxonomic distance matrix of those measured quantitative and qualitative traits using WPGMA method was calculated (not shown), and employed for dendrogram construction. The individuals collected here were grouped into twelve clusters with single to multiple species at a Euclidean distance of 0.96. The first cluster consisted of $H$. makranicum separated from all other species with brown wish pigmentation of tip of middle involucral bracts, corolla lobes recurved, lack the basal leaf and resting bud. The second cluster consisted of the populations of $H$. psychrophilum and $H$. pallasii. Third cluster included populations of $H$. artemisioides and $H$. davisianum differ from other species in having traits as achene length, branches stem and the shape of basal and middle leaf. $H$. polyphyllum, $H$. pseudoplicatum and $H$. plicatum specimens with common morphological trait as phyllaries whit longitudinal plicate and presence of buddy vertical prop separated from other species placed in forth cluster. Fifth cluster included the $H$. graveolens populations with a close relationship to fourth cluster. Sixth cluster composed of $H$. leucocephalum that differs from other species in having recurved to behind involucral bracts. Seventh cluster composed of individuals of two populations of $\mathrm{H}$. rubicundum. Eighth cluster composed of two subclusters: Oshnavieh population of $H$. glanduliferum based on yellow multi cellular achenial papillae as the diagnostic trait - comparison to other populations - with an individual of Miab population of $H$. globiferum species formed first subcluster and second subcluster that divided into two subclusters: populations of $H$. oligocephalum with two individuals of Miab population of $H$. globiferum placed in first subcluster, and $H$. araxinum with populations of $H$. oligocephalum, $H$. armenium and $H$. glanduliferum together formed second subcluster. In continues, Azerbaijan and Razan populations of $H$. oligocephalum with a close 
relationship to $H$. armenium of Semirom formed ninth cluster. The Makoo population - except to one individual - and an individual of Kaleibar population of $\mathrm{H}$. rubicundum with close relationship with Gasemlou and Naghadeh populations of $H$. aucheri along with Marand population of $H$. armenium are placed together in tenth cluster. Eleventh cluster was complex with 4 species that were consisted of: $H$. oocephalum and $H$. persicum with 34 common morphological traits - except to type and shape of lamina tip of middle involucral bracts - along populations of $H$. rubicundum and $H$. armenium. Twelfth cluster had divided into three subcluster, that $H$. rubicundum and an individual of Naghade population of $H$. aucheri plasted in first subcluster, an individual of Givi population with Kaleibar, Peygham and Tabriz populations of $H$. rubicundum plasted in second subcluster. Finally individuals and populations of $H$. armenuim, $H$. globiferum and $H$. rubicundum formed three subclusters.

Principal component analysis showed that six components explained $68.2 \%$ of the total variation which is contributed by all traits of the study (Figure 1). The first component presented $15.6 \%$ of the variation in which the stem indumentum trait was predominant in the first component and contributed most of the total variation. The second component presented $15.46 \%$ of the variation in which, attenuated resting bud and its indumen- tum, middle and upper stem leaf indumentum, achenial papillae, achene length and receptacle dimension had the highest loadings. The third component explained 10.6\% of the total variation and middle involucral bracts indumentum was dominant.

The two multivariate approaches, UPGMA and PCoA, are used in the analysis of genetic relationships within and among the sections and subgenera of Helichrysum which have produced comparable results generally.

\section{ISSR Results}

The ISSR technique is particularly powerful in discovering the genetic diversity of the genus when there is little information available for genetic characterization of species genomes. A total of 1145 PCR products were generated by 10 ISSR primers, that all of them were polymorphic. Each primer received bands from 76 (CA7AT) to 247 (CA7AC) with an average of 105 bands per primer within a size range from 100 (811) to $2000 \mathrm{bp}$ (CA7AT). Among ISSR primers, seven primers revealed the amplified DNA fragments that were unique to twelve Helichrysum species (Table 2). These ISSR primers amplifying species-specific DNA fragments would provide molecular tools for Helichrysum species authentication. We identified many putative species-specific markers.

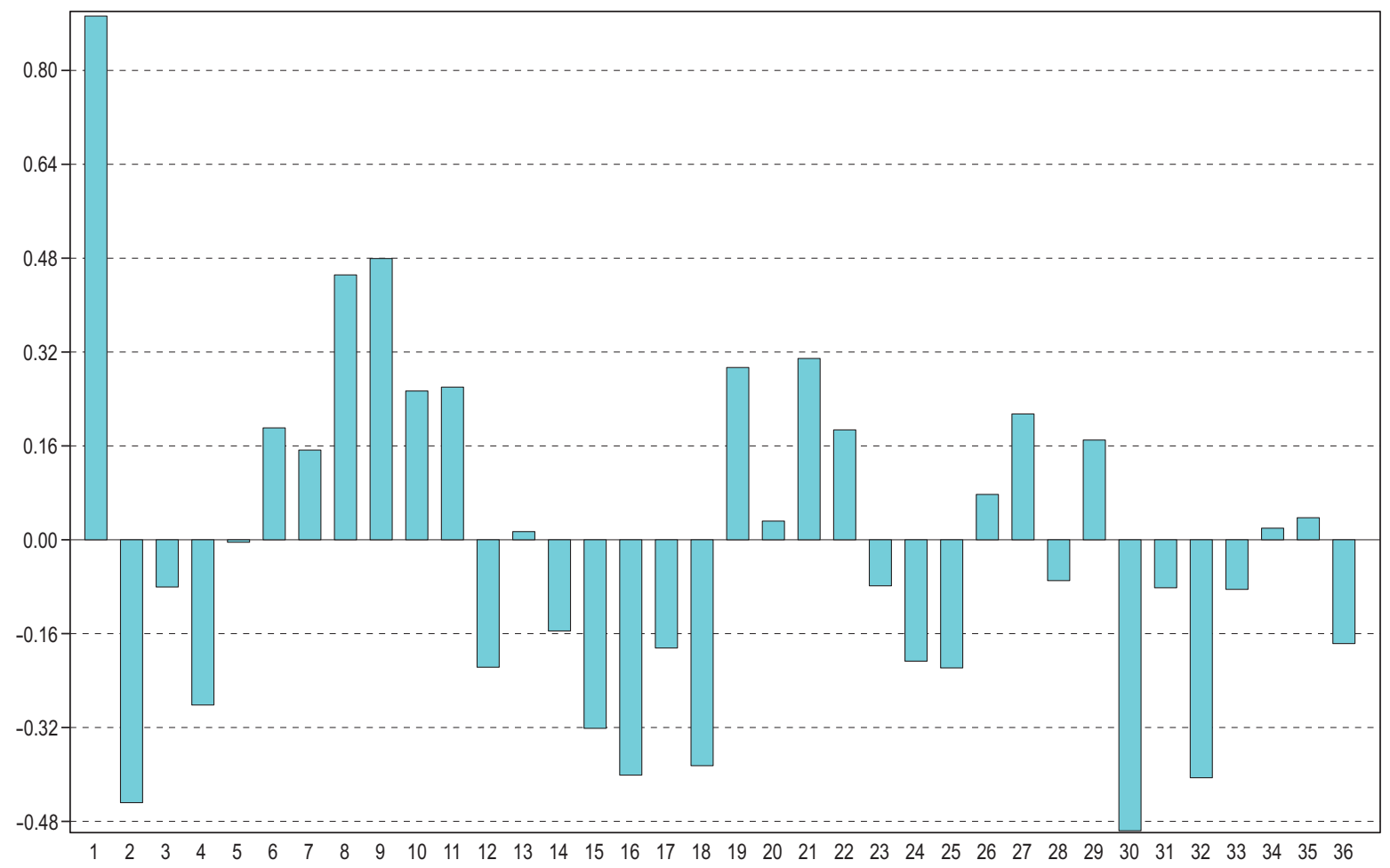

Figure 1: Contribution of the variables to component 1 (PC1).

Slika 1: Prispevek spremenljivk k prvi komponenti (PC1). 


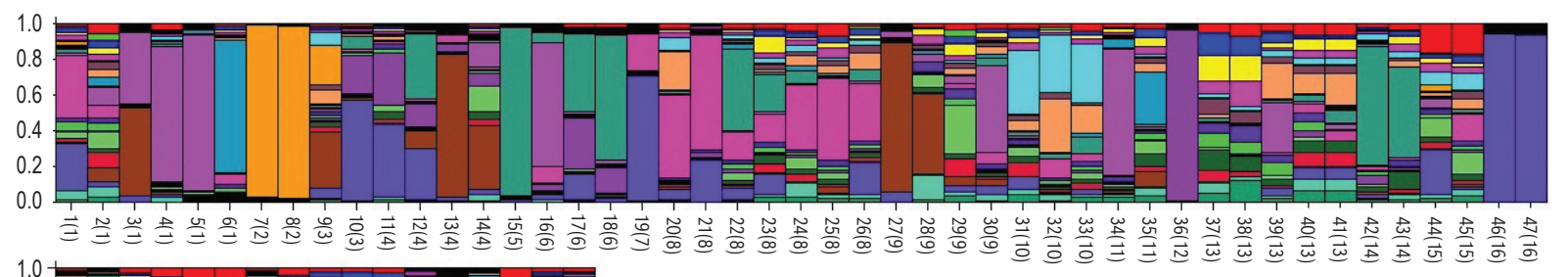

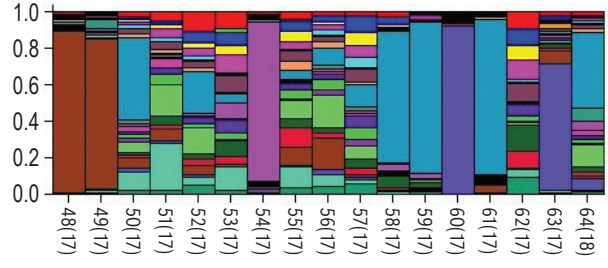

The highest gene diversity over loci (1.224), Shannon's Information Index $(0.224 \%)$ and Expected Heterozygosity $(0.142 \%)$ occurred in $H$. armenium $(0.18)$ and the lowest of these parameters $(0 \%)$ were observed in $H$. araxinum, $H$. graveolens, $H$. persicum and $H$. psychrophilum. The highest genetic similarity occurred between $H$. armenium and $H$. rubicundum (0.989), while the lowest was between H. H.polyphyllum and $H$. graveolens (0.213). The analysis of molecular variance (AMOVA), showed significant genetic variation among (24\%) and within (76\%) species the studied. The admixture estimates from STRUCTURE (Figure 2) show high degrees of gene exchange among populations.

\section{Cluster analysis based on the ISSR genotyping profiles}

Genetic similarity for populations ranged from 0.80 to 0.99 (Table 2). The highest genetic similarity occurred between $H$. armenium and $H$. rubicundum, while the lowest was between $H$. polyphyllum and $H$. graveolens.
A dendrogram was constructed to infer phylogenetic relationships by using $\mathrm{NJ}$ method, the total number of amplified ISSR fragments was considered among 64 populations of 18 Helichrysum species and it was consisted of six well-supported distinct clusters (Figure 3). The first cluster was consisted of eight species: Helichrysum pallasii and $H$. psychrophilum were placed close together, $H$. davisianum, $H$. artemisioides and $H$. makranicum, $H$. oocephalum and $H$. persicum along an individual of $13 \mathrm{~km}$ Naghadeh population of $H$. rubicundum were placed in this cluster. The second cluster was mostly combined with 10 species that were sub grouped into two subclusters: first subcluster formed with five species: $H$. rubicundum, $H$. armenium, $H$. oligocephalum $H$. plicatum, and $H$. leucocephalum and second subcluster with five species: $H$. plicatum, $H$. pseudoplicatum, H.graveolens, $H$. glandoliferum and $H$. globiferum. The third Cluster was divided into two subclusters: The populations of $H$. makranicum, $H$. artemisioides, $H$. araxinum, $H$. pseudoplicatum and $H$. polyphyllum Formed first subcluster and populations of $H$. globiferum were placed in second subcluster.

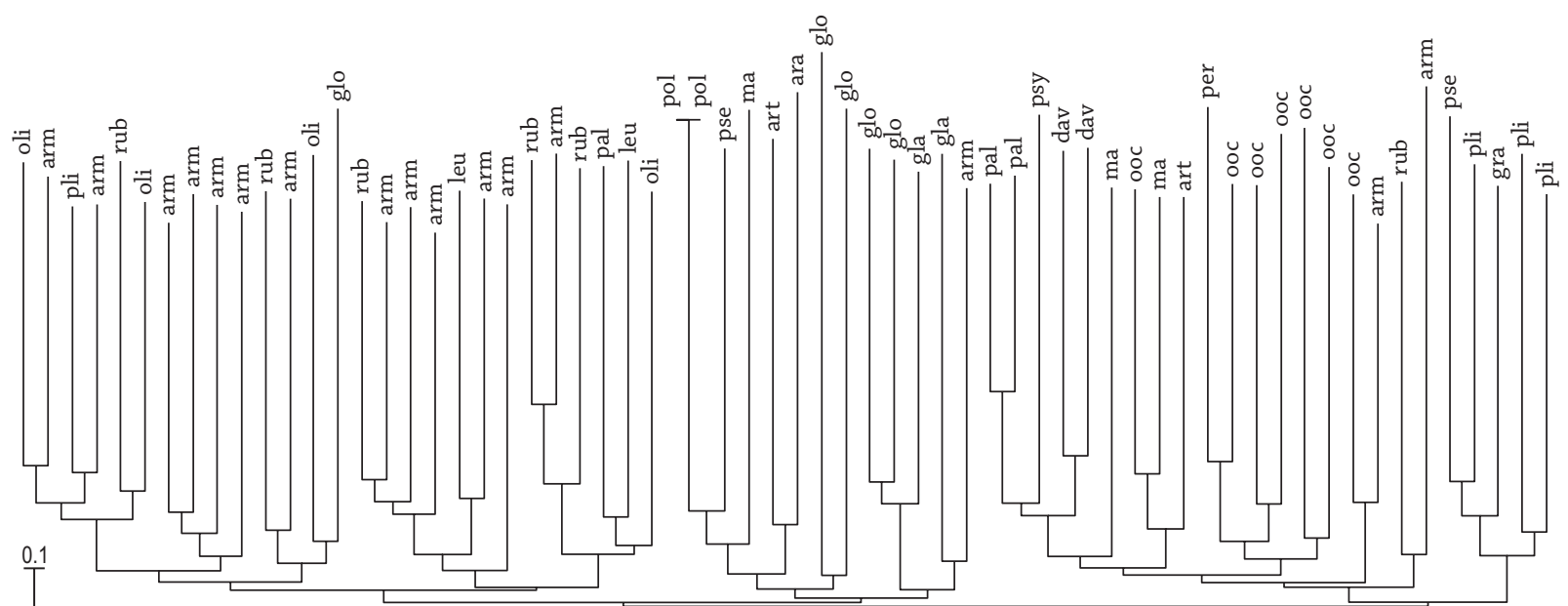

$\frac{1}{0} \quad$ Figure 3: NJ tree of molecular data in Helichrysum populations.

Slika 3: Drevo NJ molekularnih podatkov v populacijah rodu Helichrysum. 


\section{PCOA}

The principal coordinate analysis (PCoA) was performed to specify the association between populations in more detail. The overall separation pattern of the samples in PCoA plot, were in agreement with NJ molecular dendrogram (Figure 4).

The distribution pattern of many populations such as: $H$. rubicundum, $H$. armenium, $H$. globiferum populations according to ISSR dendrogram and PCoA analysis were confirmed by hierarchical AMOVA substantially, showing that $80 \%$ of the overall variation was attributed to variation within each species, whereas only $20 \%$ was due to variation among different species.
A dendrogram based on the combined (Figure 5) ISSR marker and morphology data from 61 populations was constructed in order to generate more robust results. Totally four major clusters were formed, the first comprising the $H$. glanduliferum, populations of $H$. armenium and $H$. globiferum. Second cluster included two subgroups: one was included the populations of the H. globiferum, the second subgroup was included $H$. plicatum and $H$. pseudopolicatum with a close relationship with $H$. Pseudoplicatum.

The third cluster was made up from four subclusters: a population of $H$. armenium was the outer of the other subgroups, Second subcluster was included $H$. armenium and a population of $H$. globiferum. The third subcluster was formed from $H$. leucocephalum and fourth subcluster was consisted of $H$. armenium populations.

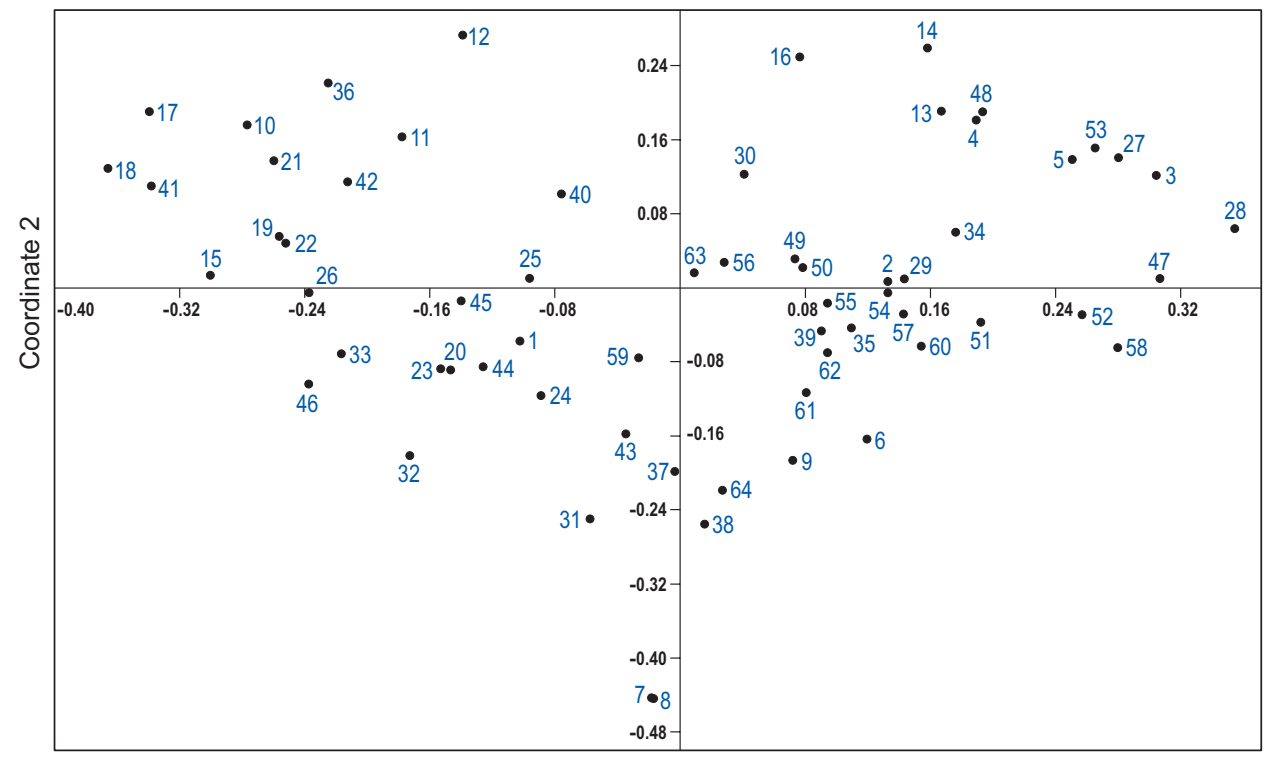

Coordinate 1
Figure 4: PCoA plot of Helichrysum species based on morphological data. Slika 4: Diagram PCoA morfoloških podatkov vrst rodu Helichrysum.

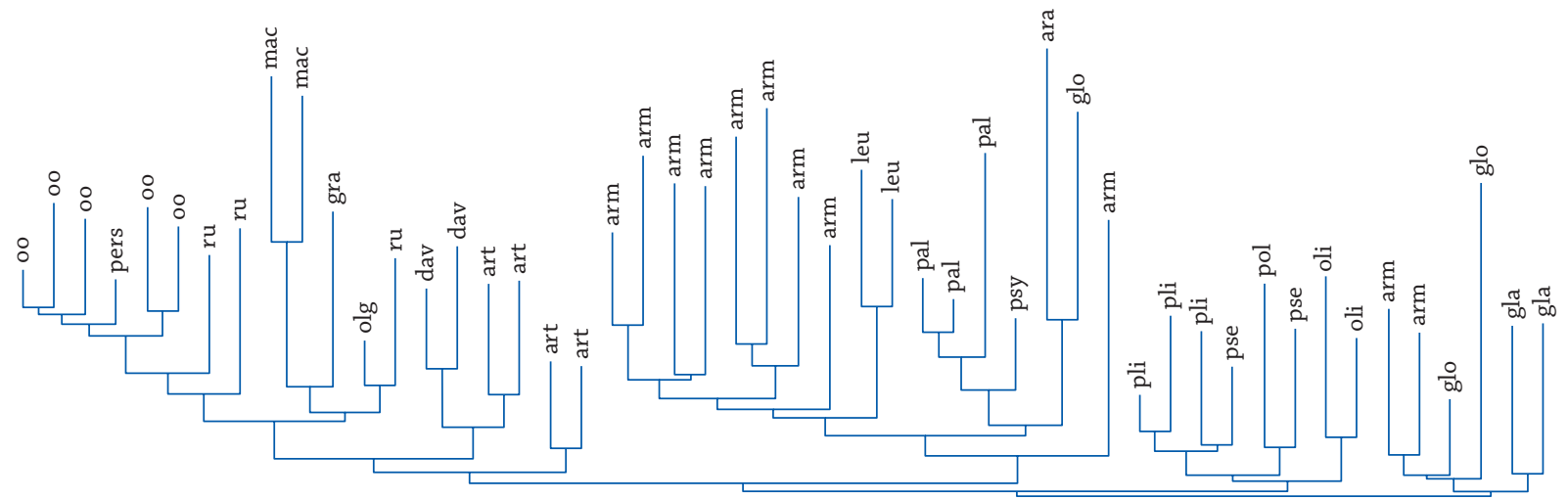

Figure 5: NJ tree based on the combined ISSR marker and morphology data.

Slika 5: Drevo NJ na osnovi kombinacije ISSR markerjev in morfoloških podatkov. 
Fourth cluster was divided into five subclusters: a population of $H$. armenium with $H$. araxinum wich was placed in first subcluster. $H$. artemisioides and $H$. davisianum have formed second subcluster. A population of H. rubicundum and $H$. globiferum were placed in third subcluster. $H$. makranicum and $H$. graveolens have formed fourth subcluster and in continues $H$. oocephalum, $H$. persicum and two populations of $H$. rubicundum were included at fifth subcluster.

These species were separated clearly by the principal coordinate analysis and were corresponded largely to those which were obtained through combined cluster analysis.

These data demonstrated the ISSR technique was a valuable molecular method for the authentication of medicinal plants at genomic DNA level.

\section{Discussion}

In this study, we used morphological and molecular traits in order to elucidate the systematic relationships in Helichrysum species. Some of morphological qualitative and quantitative traits were highly reproducible and informative for species identification and classification in Iranian Helichrysum plants.

For example: the absence of basal leaf and resting bud and the shape of corolla lobes traits (Discriminate $H$. makranicum from the other species) is the imported have great taxonomic value which distinguishes the $H$. makranicum from the other species. As well as basal leaf width trait is very useful for distinguishing certain $H$. davisianum and $H$. polyphyllum of other spesies.

Many authors, such as Behnke (1984), Güemes et al. (1992), Servettaz et al. (1994), Bini Maleci et al. (1995) and Mráz (1998) emphasize the great value of trichomes in modern taxonomy. The two Helichrysum species (H. coralloides and $H$. parvifolium) that both possess many unique trait states were distinguished from each other in terms of the indumentum trait (Mckenzie et al. 2014).

Traits such as stem indumentums and basal and middle leaf indumentums which are observed for Iranian Helichrysum - except in $H$. armenium and $H$. rubicundum which this trait is very variable- and is particularly useful for distinguishing species.

Totally, the trichomes found on rest bud, stems, leaves and phyllaries all species were very helpful in distinguishing species. Also, it varies considerably in $H$. rubicundum and $H$. armenium species with ranges which often overlap among these taxa. However, it remains trait as a very useful trait for distinguishing species.

Phyllaries are always densely or laxly arranged imbricate in outer, medial and inner rows of Helichrysum species, that the type of imbricate is helpful trait in distinguishing species in Helichrysum sect. stoachadina and Sicilian Helichrysum (Galbany et al. 2011, Puglia et al. 2016). It remains as a very useful trait for distinguishing certain pairs of taxa that lack any other distinctive feature: for example, it is useful to distinguish the Sicilian specimens of $H$. italicum from the remaining specimens of $H$. italicum subsp. italicum. In our study shape and indumentum traits of phyllaries traits were also helpful in distinguishing species.

The Ratio of Innermost phyllaries length to middle phyllaries length trait is helpful in distinguishing species of $H$. sect. Stoechadina from $H$. sect. Virginea (GalbanyCasals et al. 2011, personal observation).

The thickness of stem trait in $H$. davisianum, $H$. artemisioides and $H$. polyphyllum is the imported taxonomic value which distinguishes them from the other species. However, stem thickness can be very variable in $H$. armenium, $H$. rubicundum, $H$. aucheri and $H$. globiferum too.

Among quantitative traits, receptacle dimension and achene length are valuable for distinguishing species from each other. The achenial papillae trait is used for distinguishing Helichrysum species (Galbany-Casals et al. 2011, personal observation). We observed types of achenial papillae are consisted of yellow/white duplex hair and yellow/orange multi cellular biseriate glandular hairs on the achane surfaces of Helichrysum species, that was important in species characterization. The yellow duplex hairs were present on the achane surfaces of $H$. davisianum and in $H$. artemisioides, were mixed with duplex hairs, while the white duplex hairs were present on the achane surfaces of other species. A population of $H$. glanduliferum has yellow/ orange multi cellular biseriate glandular hair.

Some results obtained were not in agreement with the literature. In our analyses, $H$. graveolens have attenuated resting bud, whereas in Flora Iranica (Rechinger et al. 2009), they always lack resting bud or stable resting bud.

In Flora Iranica, absence or presence of lateral stem and the number of involucre bracts are very diagnostic traits for distinguishing $H$. artemisioides of $H$. davisianum. But in our observation, both species overlap in terms of these trait. Helichrysum artemisioides is closely related to $H$. davisianum, they share 32 qualitative and quantitative traits, both having a similar habit, slim and branching stems, narrow basal and stem leaf, turbinate capitula with linear phyllaries and long achene with abtuse pappus hairs apical cell. However, they were different in terms of some features, since $H$. artemisioides specimens are usually glandular, with oblanceolate or oblanceolate-spathulate basal leaf and whit glandular in part of tomentose inner involucral bracts, whereas $H$. davisianum specimens are 
usually lanate or tomentose glandular, with linear basal leaf, tomentose or tomentose- glandular inner involucral bracts. But since they are very similar and closely related it remains quite difficult to identify valid qualitative morphological traits in order to distinguish these species. Flora Iranica accepted the existence of two species mainly based on two traits: $H$. artemisioides compared to $H$. davisianum specimens have branched stem and sometimes with single capitula but in our observation these traits overlap. Consequently, due to these reasons, we suggested that the $H$. artemisioides at the sub specific level under $H$. davisianum, although more information is required in order to conclude. The molecular and morphological studies showed that there is a high degree of variability in $H$. rubicundum and $H$. armenium.

Results of morphological and molecular cluster analysis showed that the separation was in good agreement with their botanical classification, and inter/ intra species relationships were greatly in agreement with affinities which are suggested in Flora Iranica (Georgiadou et al. 1980). For example: $H$. artemisioides and $H$. davisianum showed close relationships together. As well as $H$. pallasii is closely related to $H$. psychrophilum. In fact, they shared many common qualitative morphological traits, both of them are having tomentose indumentum big capitula size with sub hemispherical to hemispherical shape, and densely or moderatly imbricate phyllaries. Although, $H$. psychrophilum specimens and $H$. pallasii specimens can be usually separated by papuss bristles traits, as well as $H$. psychrophilum specimens are usually shorter and they have more ratios of innermost phyllaries length / outermost phyllaries length.

H. plicatum, $H$. pseudoplicatum and $H$. polyphyllum specimens were gathered together in one cluster due to presence of vertical buddy prop and longitudinal plicate of phyllaries. Although according to our molecular and morphological studies, $H$. plicatum and $H$. pseudoplicatum are generally more similar. They share many common features of leaf and flowers morphology and have the same stem indumentum trait. According to Flora of Turkey (Davis et al. 1975), these species are accepted at the sub species level under $H$. plicatum. In fact, these two species are different in some traits: $H$. plicatum exhibits much variability in leaf shape, dimension and indumentums, moreover this species has slightly larger capitula than $H$. pseudoplicatum and sometimes they have heterogamous capitula, whereas $H$. pseudoplicatum has always homogamus capitula. So in agreement with Flora Iranica, we believe that these taxa are different species.

$H$. polyphyllum differs in some qualitative and quantitative features such as: resting bud indumentums, stem thickness, involucrral bract imbricate, receptacle dimen- sions, basal leaf width and number of flower per capitula. $H$. polyphyllum species has \pm glabrous resting bud whereas $H$. plicatum and $H$. pseudoplicatum have tomentose or lanate resting bud, $H$. polyphyllum usually is taller with ticker stem, dense involucral bract, with wider basal leaves and larger receptacle and it has the most number of flower, although, according to Flora Iranica some overlap traits, are in disagreement with the species affinities suggested in Flora orientalis, according to molecular and morphological traits, we concluded that exact separation is clear between them.

Some results which obtained were not in agreement with the literature of Flora Iranica, for example: $H$. rubicundum with a wide and continuous distribution area, large populations is a variable taxon, particularly regarding the indumentum and the habit trait. There are ascendent or decumbent specimens with types of lanate, lanate - glandular, tomentose; tomentose in part glandular stem indumentums and, tomentose- lanate, tomentose- glandular and lanate- glandular indumentums on greenish leaves that usually have revolute margins, although leaves can be observed with flat margins. The yellow, orange, purple or red inner involucral bracts are convex oblanceolate or ovate. After studying numerous representative specimens, we believe that this variability reflects phenotypic plasticity.

Finally, while Flora Iranica describes the absence resting buddy prop as a diagnostic trait for $H$. rubicundum, on some specimens, we have observed that present them on vegetative stems. $H$. rubicundum species are founds in different regions of west, north and center parts of Iran, in a wide range of ecological conditions, while H.aucheri grows in small area of $H$. rubicudum niche, in western Azerbaijan. Both species are closely related together and are difficult to distinguish. In fact, they do not differ in any qualitative and quantitative trait, although these traits sometimes overlap. Flora Iranica describes these taxa and distinguishes $H$. rubicundum from $H$. aucheri as distinct species, based on several morphological traits: $H$. rubicundum having basal resting bud ovate, 6-9 mm diameter, oblanceolate basal leaf, convex and wide oblanceolate intermedial phyllaries with transverse compression, 34-36 flowers with $2.8-3.6 \mathrm{~mm}$ long, achene 0.8-1.2 mm long with 22-23 obtuse pappus, and $H$. aucheri having basal resting bud elliptic or ovate, $\pm 10-12$ $\mathrm{mm}$ diameter, oblanceolate-spathulate basal leaf, flat and narrow lanceolate-spathulate intermedial phyllaries with truncate or rotundate apex, 43-48 flowers with 4-5 mm long, achene 1-1.5 mm long with 28-35 clavate pappus. But based on our study on numerous specimens, there are no unique traitistics for each of the species because these traitistics overlap and the separation between them is not 
clear, except flowering time that $H$. rubicudum often is distinguishable due its involucres color.

Following these reasons, we combined $H$. aucheri at the sub specific level under $H$. rubicundum.

Ghahremaninejad et al. (2004) described a specimen of Helichrysum of Torbat Heydarieh as a new endemic species under the name $H$. persicum. They stated, $H$. persicum is closely related to $H$. artemisioides and $H$. davisianum in terms of having obconic capitula and differs from those species interms of having shorter and unbranched flowering stem, more bulky resting bud, wider inflorescence, shorter involucre, in a lower number of florets and pale yellow to brown phyllaries than those of $H$. artemisioides and more number of puppi than those of $H$. davisianum. But according to our analysis, $H$. persicum is more closely related to $H$. oocephalum with a wide and continuous distribution area in north, northeast and east parts of Iran, it is mostly a rather variable species whereas $H$. persicum consists of a specimen which is located in a single location. In addition to our own data which was collected from field observations, we weren't able to find any specimen of this taxon in its location.

In fact, they do not differ in any qualitative and quantitative trait, and both have a similar habit, basal resting bud, lanate- glandular stem indumentum, capitula with hermaphrodite flowers whit white duplex hair on achene surface. Anyway, all traits of $H$. persicum fits within the range of $H$. oocephalum morphological variability -for example: hemispherical to sub hemispherical or $( \pm)$ turbinate. Following these reasons and molecular data, we considered $H$. persicum as a specimen of $H$. oocephalum.

\section{Conclusions}

In Iran, some of Helichrysum taxa have a wide distribution area with a common ecological niches and form populations together, that are not clearly recognizable from each other. Thus phenotypic plasticity is an explanation for their morphological variation, also there may be a genetic component regarding the morphological differences.

A high degree of similarity was observed between morphological and molecular clusters, it were in good agreement with Flora Iranica. According to both data: $H$. artemisioides, $H$. davisianum and $H$. makranicum have close relationship. So $H$. graveolens, $H$. polyphyllum, $H$. pseudoplicatum and $H$. plicutum were placed close together, H. psychrophilum and $H$. pallasii confirmed a close relationship and in the following, close relationship between $H$. leucocephalum, H. globiferum and H. rubicundum was in good agreement with their botanical classification.
Although, results of morphological cluster analysis showed an unclear delimitation between specimens and populations of $H$. armenium, $H$. rubicundum and $H$. globiferum, according to molecular data, this disorder was observed in $H$. armenium, $H$. rubicundum and H. oligocephalum. These species mostly overlap in distribution area and analysis showed sharing gene between them - according to STRUCTURE - this may be as a result of hybridization to which is in agreement with Taban et al. (2015).

Our results showed high level of variability at both morphological and molecular levels. However, when molecular markers and quantitative traits were analyzed in the same plant material, more conclusive information was obtained.

Masoud Sheidai (D), https://orcid.org/0000-0003-3983-6852 Zahra Noormohammadi (D, https://orcid.org/0000-00033890-9001

\section{References}

Anderberg, A. A. 1991: Taxonomy and Phylogeny of Tribe Gnaphalieae (Asteraceae). Opera Botanica 104: 1-195.

Antunes Viegas, D., Palmeira de Oliveira, A., Salgueiro, L., de Oliveira, J. M. \& Palmeira de Oliveira, R. 2013: Helichrysum italicum: from traditional use to scientific data. Journal of Ethnopharmacology 151: $54-65$.

Azizi, N., Sheidai, M. \& Mozafarian, V. 2014: Species relationships in the genus Helichrysum Mill. (Asteraceae) based on morphological characters in Iran. European Journal of Experimental Biology 4(1): 603-607.

Azizi, N., Sheidai, M., Mozaffarian, V. \& Noormohammadi, Z. 2014: Genetic, cytogenetic and morphological diversity in Helicrysum leucocephalum (Asteraceae) populations. Biologia 69: 566-573.

Bayer, R. J., Breitwieser, I., Ward, J. \& Puttock, C. F. 2007: Gnaphalieae. in Kadereit JW, C Jeffrey, C. (eds): The families and genera of vascular plants. Vol VIII. Asterales. Springer, Berlin. p: 246-284.

Bayer, R. J., Puttock, C. F. \& Kelchner, S. A. 2000: Phylogeny of South African Gnaphalieae (Asteraceae) based on two non-coding chloroplast sequences. American Journal of Botany 87: 259-272.

Behnke, H. D. 1984: Plant trichomes - structure and ultrastructure In Rodriguez E, PL Healey and Metha, I. (eds): Biology and chemistry of plant trichomes. Plenum Press, New York, p: 1-21

Bini Maleci, L., Pinetti, A. \& Servettaz, O. 1995: Micromorphological and phytochemical characters of the two subspecies of Teucrium flavum (Labiatae) from the Italian flora. Flora 190: 237-242.

Butcher, P. A., Matheson, A. C. \& Slee, M. U. 1996: Potential for genetic improvement of oil production in Melaleuca alternifolia and $M$. linariifolia. New Forests 11:31-51.

Chamorro, E. R., Zambón, S. N., Morales, W. G., Sequeira, A. F., \& Velasco, G. A. 2012: Gas chromatography in plant science, Wine 
technology, toxicology and some specific applications. In: Salih, B. \& Çelikbıçak, O. (eds): Study of the Chemical Composition of Essential Oils by Gas Chromatography. InTech press. p. 307-324.

Davis, P. H. \& Kupicha, F. K. 1975: Flora of Turkey. vol. 5: 80-97.

Dhar, R. S., Verma, V., Suri, K. A., Sangwan, R. A., Satti, N. K. \& Kumar, A. (2006). Phytochemical and genetic analysis in selected chemotypes of Withania somnifera. Phytochemistry 4: 45-46.

Freeland, J. R., Kirkland, S. \& Petersen, D. 2011: Molecular Ecology, $2^{\text {nd }}$ ed. Willy-Blackwell, London, $464 \mathrm{p}$.

Galbany- Casals, M., Unwin, M. W., Garcia- Jacas, N., Smissen, R. D., Susanna, A. \& Bayer R. J. 2014: Phylogenetic relationships in Helichrysum and related genera incongruence between nuclear and plastid phylogenies, biogeographic and morphological patterns, and implications for generic delimitation. Taxon 63 (3): 608-624.

Galbany-Casals, M., Blanco-Moreno, J. M., Garcia-Jacas. N, Breitwieser, I. \& Smissen, R. D. 2011: Genetic variation in Mediterranean Helichrysum italicum (Asteraceae; Gnaphalieae): do disjunct populations of subsp. microphyllum have a common origin? Plant Biology. 13:678-687.

Galbany-Casals, M., Susanna, A. \& Briones, J. M. 2009: Low base numbers and dysploidy in annual Helichrysum Mill. (Asteraceae: Gnaphalieae). Acta Biologica Cracoviensia Series Botanica 51:107-114.

Galbany-Casals, M., Saez , L. \& Benedi, C. 2006: a taxonomic revision of Helichrysum sect. Stoechadina (Asteraceae, Gnaphalieae). Canadian Journal of Botany 84(8): 1203-1232.

Galbany-Casals, M., Saez, L., \& Benedi, C. 2004: Taxonomy of Castroviejoa, a new genus of Gnaphalieae (Asteraceae), endemic to the Mediterranean Islands Corsica and Sardinia. Australian Systematic Botany 17: 581-591.

Galbany-Casals, M., Garcia-Jacas, N., Susanna, A., Saez, L., \& Benedi, C. 2004: Phylogenetic relationships in the Mediterranean Helichrysum (Asteraceae, Gnaphalieae) based on nuclear rDNA ITS sequence data. Australian Systematic Botany 17: 241-253.

Galbany-Casals, M., Garcia-Jacas, N., Sa'ez, L., Benedi, C. \& Susanna, A. 2009: Phylogeny, biogeography, and character evolution in Mediterranean, Asiatic, and Macaronesian Helichrysum (Asteraceae, Gnaphalieae) inferred from nuclear phylogenetic analyses. International Journal of Plant Science 170: 365-380.

Galbany-Casals, M., Carnicero- Campmany, P., Blanco- Moreno, J. M. \& Smissen, R. D. 2012: Morphological and genetic evidence of contemporary intersectional hybridisation in Mediterranean Helichrysum (Asteraceae, Gnaphalieae). Plant Biology 14: 789-800.

Galbany-Casals, M., Andres-Sanchez, S., Garcia-Jacas, N., Susanna, A., Rico, E. \& Martinez-Ortega, M. M. 2010: How many of Cassini anagrams should there be? Molecular systematics and phylogenetic relationships in the Filago group (Asteraceae, Gnaphalieae), with special focus on the genus Filago. Taxon 59: 1671-1689.

Gaustafsson, M. H. G. \& Bremer, K. 1995: Morphology and Phylogenetic inter relationships of the Asteraceae, Calyceraceae, Campanulaceae, Goodinaceae, and related families (Asteraceae). Amrican journal of Botany 82: 250-262.

Georgiadou, E. \& Rechinger, K. H. 1980: Flora of Iranica. 145: 51-72.

Ghahramaninejad, F. \& Noori, N. 2005: Reported a new species of the genus Helichrysum as: H. persicum F. Ghahramani \& Noori for Iran. Annales Botanici Fennici 49: 73-76.
Güemes, J., Mateo, G. \& Crespo, M. B. 1992: Importancia de los tricomas en la taxonomía del grupo Teucrium buxifolium Schreber. In: Conesa, JA. \& Recasens, (eds): Actes del Simposi International de Botřnica Pius Font i Quer 1988.Vol 2. Fanerogamia, Pp. 155-159.

Hamer, O. M., Harper, D. A. T. \& Ryan, P. D. 2012: PAST: Paleontological Statistics software package for education and data analysis. Palaeontologia Electronica 4: 9.

Hilliard, O. M. \& Burtt, B. L. 1981: Some generic concepts in Compositae- Gnaphaliinae. Botanical Journal of the Linnean Society 82: 181-232.

Hilliard, O. M. 2011: Helichrysum Mill.: Leistner, OA. (eds): Flora of southern Africa Botanical Research Institute, Pretoria, p. 61-310.

Hong, D. Y. Q., Lau, A. J., Leo, C. L., Kiu, X. K. \& Yang, Y. 2005: Genetic diversity and variation of saponin contents in Panax notoginseng roots from a single farm. Journal of Agricultural and Food Chemistry 53: 8460-8467.

Javidnia, K., Miri, R., Soltani, M. \& Khosravi, A. R. 2009: Essential oil composition of two Iranian endemic Helichrysum Miller. species (H. leucocephalum Boiss. and H. artemisioides Boiss. et Hausskn.). Journal of Essential Oil Research 21: 54-56.

Križman, M., Baričević, D. \& Prošek, M. 2006: Fast quantitative determination of volatile constituents in fennel by heads pacegas chromatography. Analytica Chimica Acta 557: 267-271.

Križman, M., Jakše, J., Baričević, D., Javornik, B. \& Prošek, M. 2006: Robust CTAB-activated charcoal protocol for plant DNA extraction. Acta Agriculturae Slovenica 87: 427-433.

Laitinen, M. L. 2003: Variation in secondary chemistry within a natural population of birch: Effects of genotype, environment and ontogeny. PhD Diss., University of Joensuu, 98 p.

Leach, G. L. \& Whiffin, T. 1989: Ontogenetic, seasonal and diurnal variation in leaf volatile oils and leaf phenolics of Angophora costata. Australian Systematic Botany 2: 99-111.

Mckenzie, R. J., Ward, M. J., Lovis, J. D. \& Breitwieser, I. 2004: Morphological evidence for natural intergeneric hybridization in the New Zealand Gnaphalieae (Compositae): Anaphalioides bellidioides $\times$ Ewartia sinclairii. Botanical Journal of the Linnean Society 145 : 59-75.

Meirmans, P. G. \& Van Tienderen, P. H. 2004: Genotype and Genodive: two programs for the analysis of genetic diversity of asexual organisms. Molecular Ecology Notes 4: 792-794.

Mráz, P. 1998: The structure and development of the glandular trichomes of Teucrium montanum (Lamiaceae). Biologia 53:65-72.

Pavia, H., Toth, G. B., Lindgren, A. \& Aberg, P. 2003: Intraspecific variation in the phlorotannin content of the brown alga Ascophyllum nodosum. Phycologia 42(4): 378-383.

Plumer, J. A., Wann, J. M. \& Spadek, Z. E. 1999: Intraspecific Variation in Oil Components of Boronia megastigma Nees. (Rutaceae) Flowers. Annals of Botany 83: 253-262.

Podani, J. 2000: Introduction to the Exploration of Multivariate Data [English translation], Leiden, Netherlands. Backhuyes, 455 p.

Pritchard, J. K., Stephens, M. \& Donnelly, P. 2000: Inference of population structure using multilocus genotype. Data. Genetics 155 : 945-959. 
Puglia, G., Grimaldi, S., Pavone, P. \& Spampinato, G. 2016: Genetic and morphological variability analysis revealed a complex network in South-Eastern Sicilian Helichrysum occurrences. Plant Biosystems 152: $142-151$

Sabetta, W. Montemurro, C., Perrini, R., Morone Fortunato, A. Blanco, A., 2006: Genetic diversity assessment of Helichrysum italicum (Roth.) Mediterranean germplasm by AFLP markers. Proceedings of the 50th Italian Society of Agricultural Genetics Annual Congress. Ischia, Italy.

Scora, R. W. \& Torrisi, S. 1966: Relation of taxonomic, climatic and tissue maturity factors to the essential oil constituents in leaves and fruits in the Aurantioideae. Proceedings of the American Society for Horticultural Science 88: 262-271.

Servettaz, O., Pinetti, A., Bellesia, F. \& Bini Maleci, L. 1994: Micro morphological and photochemical research on Teucrium scorodonia and Teucrium siculum from the Italian flora. Botanica Acta 107: 416-421.
Skogerson, K., Harrigan, G. G., Reynolds, T. L., Halls, S. C., Ruebelt, M., Iandolino, A., Pandravada , A., Glenn, K. C. \& Fiehn, O. 2010: Impact of genetics and environment on the metabolite composition of maize grain .Journal of Agricultural Food Chemistry 24: 58(6): 3600-3610.

Taban, M., Sheidai, M., Noormohammadi, Z., Azizi, N., Ghasemzadeh- Baraki \& S., Koohdar, F. 2015: Population Genetic Analysis and Evidence of Inter-Specific Introgression in Helichrysum armenium and H. rubicundum (Asteraceae). Genetika 2: 451-468.

Weising, K., Nybom, H., Wolf, K. \& Kahl, G. 2005: DNA Fingerprinting in Plants. Principles, Methods, and Applications. (2 ${ }^{\text {nd }}$ ed.), Boca Raton, Fl., USA: CRC Press, 444 p.

Whiffin, T. \& Ladiges, P. Y. 1992: Patterns of variation and relationships in the Eucalyptus alpine-E. baxteri complex (Myrtaceae) based on leaf volatile oils. Australian Systematic Botany5: 695-709.

Table 1: Locality of Helichrysum species and populations studied.

Tabela 1: Lokacije obravnavanih populacij vrst rodu Helichrysum.

\begin{tabular}{|c|c|c|c|}
\hline No. & Species & Locality & Voucher No. \\
\hline 1 & H. $\operatorname{araxinum}^{*}$ & West- Azerbaijan Makou & HSBU2012201 \\
\hline 2 & H. armenium* & Hamadan: $12 \mathrm{~km}$ Asad - Abad & TARI47446 \\
\hline 3 & H. armenium* & West Azerbaijan: Uroumia: Mavana & HSBU2012202 \\
\hline 4 & H. armenium* & West Azerbaijan: Uroumia: Mamakan & HSBU2012203 \\
\hline 5 & H. armenium* & West Azerbaijan: Uroumia: Solouk Wateroff & HSBU2012204 \\
\hline 6 & H. armenium* & West Azerbaijan: Uroumia: Silvana & HSBU2012205 \\
\hline 7 & H. armenium* & West Azerbaijan: $15 \mathrm{~km}$ - Oshnavieh & HSBU20122006 \\
\hline 8 & H. armenium* & West Azerbaijan: 25 km Khoy - Chaldoran & HSBU2012207 \\
\hline 9 & H. armenium & East Azerbaijan: 2 km Tabriz - Ahar & HSBU2012208 \\
\hline 10 & H. armenium & East Azerbaijan: Marand & HSBU2012209 \\
\hline 11 & H. armenium & Kordestan: Marivan: Garan Col & HSBU2012210 \\
\hline 12 & H. armenium* & Kordestan: Sanandaj: Ariz Col & HSBU2012211 \\
\hline 13 & H. armenium* & Kordestan: Divan-dareh, Zagheh & HSBU2012212 \\
\hline 14 & H. armenium* & Kordestan: Abidar Park & HSBU2012213 \\
\hline 15 & H. armenium & Hamadan: 10 km Asad - Abad & HSBU2012214 \\
\hline 16 & H. armenium* & Hamadan: Asad - Abad: Aladagh & HSBU2012215 \\
\hline 17 & H. armenium & Hamadan: Heydareh & HSBU2012216 \\
\hline 18 & H. armenium* & Hamadan: Kaboodar - Ahang & HSBU2012217 \\
\hline 19 & H. armenium* & Esfahan: Semirom: Deh - Vanak & TARI62142 \\
\hline 20 & H. artemisioides* & Chaharmahal - Bakhtiari: Lordegan & TARI66101 \\
\hline 21 & H. artemisioides & Kohkilooyeh: Sisakht & TARI \\
\hline 22 & H. artemisioides* & Arak: Mahalat & TARI37836 \\
\hline 23 & H. aucheri & West Azerbaijan: 15 km - Oshnavieh & HSBU2012218 \\
\hline 24 & H. aucheri & West Azerbaijan: Near Ghasemloo & HSBU2012219 \\
\hline 25 & H. davisianum* & Yazd: Shirkooh & HSBU2012220 \\
\hline 26 & H. davisianum* & Yazd: Damgahan & TARI77715 \\
\hline 27 & H. davisianum & Espahan: Semirum & TARI31670 \\
\hline 28 & H. glanduliferum & West Azerbaijan - Solouk Waterfall & HSBU2012221 \\
\hline 29 & H. glanduliferum* & West Azerbaijan: 18 km Naghadeh - Oshnavieh & HSBU2012222 \\
\hline 30 & H. glanduliferum* & West Azerbaijan: $35 \mathrm{~km}$ Naghadeh - Oshnavieh & HSBU2012223 \\
\hline 31 & H. globiferum* & West Azerbaijan: Khoy - Chaldoran & HSBU2012224 \\
\hline
\end{tabular}




\begin{tabular}{|c|c|c|c|}
\hline No. & Species & Locality & Voucher No. \\
\hline 32 & H. globiferum* & East Azerbaijan: Payam Vilage & HSBU2012225 \\
\hline 33 & H. globiferum* & East Azerbaijan: Miab & HSBU2012226 \\
\hline 34 & H. globiferum* ${ }^{*}$ & Hamadan: Razan & HSBU2012227 \\
\hline 35 & H. graveolens & Golestan: Golestan Park & TARI12623 \\
\hline 36 & H. graveolens* & Mazandaran: Lapasar & TARI21658 \\
\hline 37 & H. graveolens & Mazandaran: Javaher - Deh & TARI56835 \\
\hline 38 & H. leucocephalum* & Fars: Abadeh - Tashk & HSBU2012228 \\
\hline 39 & H. leucocephalum* & Fars: Arsanjan Bonab Park & HSBU2012229 \\
\hline 40 & H. leucocephalum & Fars: Neyriz, Palangan & HSBU2012230 \\
\hline 41 & H. leucocephalum & Fars: Morghak Valley & HSBU2012231 \\
\hline 42 & H. leucocephalum & Yazd: Damgahan & HSBU2012232 \\
\hline 43 & H.makranicum* & Hormozgan: Bashagard, Angooran Vilage & TARI44366 \\
\hline 44 & H.makranicum & Hormozgan: Senderk, Darreh- Pahn & TARI39250 \\
\hline 45 & H.makranicum* & Hormozgan: Senderk - Arakin & TARI44458 \\
\hline 46 & H.makranicum & Hormozgan: Bashagard & TARI 44431 \\
\hline 47 & H.makranicum & Hormozgan: Jakdan - Senderk & TARI 44371 \\
\hline 48 & H. oligocephalum* & Kermanshah: Shahoo amount & HSBU2012233 \\
\hline 49 & H. oligocephalum* & Tehran: Darakeh & HSBU2012234 \\
\hline 50 & H. oligocephalum & Alborz: Vardich & HSBU2012235 \\
\hline 51 & H. oocephalum* & Khorasan: Esfarayen, Shah - Jahan & TARI48649 \\
\hline 52 & H. oocephalum* & Khorasan: Kashmar - Neyshaboor & TARI35577 \\
\hline 53 & H. oocephalum* & Khorasan: Neyshaboor, Boozhan & TARI48982 \\
\hline 54 & H. oocephalum* & Khorasan: Mashad, Dizbad & TARI48907 \\
\hline 55 & H. oocephalum* & Hormozgan: Senderk- Arakin & TARI44273 \\
\hline 56 & H. oocephalum & Hormozgan: Senderk & TARI44484 \\
\hline 57 & H. oocephalum & Hormozgan: Ghotbabad & TARI49923 \\
\hline 58 & H. pallasii* & East Azerbaijan: Haris & TARI469 \\
\hline 59 & H. pallasii ${ }^{*}$ & West Azerbaijan: Miab & HSBU2012236 \\
\hline 60 & H. pallasii* & Tehran: Shemshak & TARI49026 \\
\hline 61 & H. persicum* & Khorasan: Robat sefid & TARI21312 \\
\hline 62 & H. plicatum* & Alborz: Damavand & HSBU201237 \\
\hline 63 & H. plicatum* & East Azerbaijan: Goli - Deragh & TARI34974 \\
\hline 64 & H. plicatum* & West Azerbaijan: Uroumiah: Solouk & HSBU2012238 \\
\hline 65 & H. polyphyllum* & West Azerbaijan: Uroumiah: Solouk & HSBU2012239 \\
\hline 66 & H. pseudoplicatum* & East Azerbaijan: Mishoo - Dagh & TARI29836 \\
\hline 67 & H. pseudoplicatum & West Azerbaijan: Uroumiah: Mavana & HSBU2012240 \\
\hline 68 & H. pseudoplicatum* & West Azerbaijan: Uroumiah: Razhan & HSBU2012241 \\
\hline 69 & H. pseudoplicatum & Semnan: Shali - Hikoo & TARI40583 \\
\hline 70 & H. pseudoplicatum & Kordestan: Chehel - Cheshmeh & TARI75306 \\
\hline 71 & H. psychrophilum & Alborz: Dmavand - Tar Lake & TARI49279 \\
\hline 72 & H. psychrophilum & West Azerbaijan: Mavana & TAR69894 \\
\hline 73 & H. psychrophilum* & Mazandaran: Ramsar & TARI51214 \\
\hline 74 & H. rubicundum & East Azerbaijan: Aras River & HSBU2012242 \\
\hline 75 & H. rubicundum & East Azerbaijan: $15 \mathrm{~km}$ Tabriz & HSBU2012243 \\
\hline 76 & H. rubicundum* & East Azerbaijan: $22 \mathrm{~km}$ Tabriz- Ahar & HSBU2012244 \\
\hline 77 & H. rubicundum & East Azerbaijan: $25 \mathrm{~km}$ to Tabriz, & HSBU2012245 \\
\hline 78 & H. rubicundum & West Azerbaijan: Salmas & HSBU2012246 \\
\hline 79 & H. rubicundum & East Azerbaijan: 2 km Tabriz - Ahar & HSBU2012248 \\
\hline 80 & H. rubicundum* & East Azerbaijan: Poldasht & HSBU2012249 \\
\hline 81 & H. rubicundum & Alborz: Damavand & HSBU2012250 \\
\hline
\end{tabular}




\begin{tabular}{|c|c|c|c|}
\hline No. & Species & Locality & Voucher No. \\
\hline 82 & H. rubicundum & Zanjan: Soltanieh & HSBU2012251 \\
\hline 83 & H. rubicundum & Ardabil: Lahrood- ghotoor soo & HSBU2012252 \\
\hline 84 & H. rubicundum* & West Azerbaijan: Kaleibar - Rend & HSBU2012253 \\
\hline 85 & H. rubicundum & East Azerbaijan: Kaleibar - Aras & HSBU2012254 \\
\hline 86 & H. rubicundum & 43 km Ardabil - Givi & HSBU2012255 \\
\hline 87 & H. rubicundum & $24 \mathrm{~km}$ Ardabil - Givi & HSBU2012256 \\
\hline 88 & H. armenium• & East Azerbaijan: Marand: Mishoodagh & HSBU2012258 \\
\hline 89 & H. armenium• & East Azerbaijan: East of Mishoodagh & HSBU2012259 \\
\hline 90 & H. armenium• & West Azerbaijan: Marand: Kiamaki - Dagh & HSBU2012260 \\
\hline 91 & H. globiferum• & West Azerbaijan: Marand: Kiamaki - Dagh & HSBU2012268 \\
\hline 92 & H.makranicum• & Sistan and Balouchestan: Jazmoorian & TARI22922 \\
\hline 93 & H. oligocephalum• & West Azerbaijan: Urumiah: Khalil - Kooh & HSBU2012269 \\
\hline 94 & H. oligocephalum $\bullet$ & Kordestan: Marivan - Sanandaj & HSBU2012261 \\
\hline 95 & H. plicatum $\bullet$ & West Azerbaijan: Ghasemloo Valley & HSBU2012257 \\
\hline 96 & H. polyphyllum• & West Azerbaijan: Urumiah: Silvana & HSBU2012264 \\
\hline 97 & H. oocephalum• & Hormozgan: Senderk - Darrepahn & TARI44485 \\
\hline 98 & H. оocephalum• & Khorasan: Mashhad: Shah - Taghi & HSBU2012263 \\
\hline 99 & H. rubicundum $\bullet$ & West Azerbaijan: Oshnavieh & HSBU2012265 \\
\hline 100 & H. rubicundum $\bullet$ & West Azerbaijan: $13 \mathrm{~km}$ Naghadeh - Oshnavieh & HSBU2012266 \\
\hline 101 & H. rubicundum• & West Azerbaijan: Urumiah: Silvana & HSBU2012267 \\
\hline
\end{tabular}

Note: populations 1 to 87 : populations included only in the morphological analyses, ${ }^{*}$ : populations included in the morphological and molecular analyses, $\bullet$ : populations included only in the molecular analyses

Table 2: Genetic diversity parameters in Helichrysum species.

Tabela 2: Dejavniki genetske raznolikosti pri vrstah rodu Helichrysum.

\begin{tabular}{lllllrr}
\hline Species & $\mathbf{N a}$ & $\mathrm{Ne}$ & $\mathrm{I}$ & $\mathrm{He}$ & $\mathrm{UHe}$ & \multicolumn{1}{c}{$\mathbf{\text { U }} \%$} \\
H. araxinum & 0.021 & 1.000 & 0.000 & 0.000 & 0.000 & $0.00 \%$ \\
H. armenium & 1.082 & 1.224 & 0.224 & 0.142 & 0.148 & $54.11 \%$ \\
H. artemisioides & 0.356 & 1.107 & 0.091 & 0.062 & 0.083 & $15.07 \%$ \\
H. davisianum & 0.233 & 1.063 & 0.054 & 0.037 & 0.049 & $8.90 \%$ \\
H. glandoliferum & 0.342 & 1.107 & 0.091 & 0.062 & 0.083 & $15.07 \%$ \\
H. globiferum & 0.918 & 1.208 & 0.212 & 0.135 & 0.149 & $45.89 \%$ \\
H. graveolens & 0.110 & 1.000 & 0.000 & 0.000 & 0.000 & $0.00 \%$ \\
H. Leucocephalum & 0.363 & 1.107 & 0.091 & 0.062 & 0.083 & $15.07 \%$ \\
H. makranicum & 0.603 & 1.177 & 0.158 & 0.106 & 0.127 & $28.77 \%$ \\
H. oligocephalum & 0.658 & 1.162 & 0.159 & 0.103 & 0.117 & $32.19 \%$ \\
H. oocephalum & 0.699 & 1.104 & 0.123 & 0.073 & 0.078 & $34.25 \%$ \\
H. pallasii & 0.247 & 1.065 & 0.059 & 0.039 & 0.047 & $10.96 \%$ \\
H. persicum & 0.020 & 1.000 & 0.000 & 0.000 & 0.000 & $0.00 \%$ \\
H. plicatum & 0.322 & 1.082 & 0.079 & 0.052 & 0.062 & $15.07 \%$ \\
H. polyphyllum & 0.096 & 1.000 & 0.000 & 0.000 & 0.000 & $0.00 \%$ \\
H. pseudoplicatum & 0.301 & 1.102 & 0.087 & 0.060 & 0.079 & $14.38 \%$ \\
H. psychrophilum & 0.034 & 1.000 & 0.000 & 0.000 & 0.000 & $0.00 \%$ \\
H. rubicundum & 0.726 & 1.147 & 0.154 & 0.096 & 0.105 & $36.30 \%$ \\
\hline
\end{tabular}

Abbreviations: $\mathrm{Na}=$ No. of different alleles, $\mathrm{Ne}=$ No. of effective alleles $=1 /\left(\mathrm{p}^{2}+\mathrm{q}^{2}\right), \mathrm{I}=$ Shannon's information index $=-(\mathrm{p}$ Ln $(\mathrm{p})+$ $\mathrm{qLn}(\mathrm{q})), \mathrm{He}=$ Expected heterozygosity $=2 \mathrm{pq}$, and $\% \mathrm{P}=$ Percentage of polymorphism 
Table 3: Traits for Helichrysum species.

Tabela 3: Znaki za vrste rodu Helichrysum.

01 Stem indumentum: 1- tomentose; tomentose in part glandular; 2- tomentose- glandular; 3-glandular; 4- lanate;

5- lanate- glandular

02 Stem form: 1-procumbent; 2: erect approximately erect

03 Thickness of stem: 1- thin; 2- medium; 3- thick

04 Leaf density: 1-dense; 2- moderate; 3- sparse

05 Attenuated resting bud: 1- present; 2: absent

06 Resting bud indumentums: 1- tomentose, lanate; 2-glandular; 3: \pm glabrous

07 Basal leaf shape: 1- oblanceolate, oblanceolate-spathulate ; 2- liner

08 Middle stem leaves leaf indumentums: 1- tomentose, tomentose- lanate, tomentose- glandular; 2- Glandular in part lanate; 3- glandular; 4- lanat- glandular

09 Upper stem leaves indumentums: 1- tomentose, tomentose lanate, tomentose glandular; 2- glandular in part tomentose or lanate; 3- glandular

10 Inflorcense type: 1 - ; 2- corymbose

11 Involucre shape: 1 - turbinate or \pm turbinate; 2 - non turbinate

12 Heterogamy: 1- hermaphrodyt; 2- heterophrodyt; 3-hetero and hermafer

13 Involucrral bract color; 1-yellow; 2-white, cream; 3- orange, purple, red

14 Involucrral bract Imbricate: 1-dense; 2- \pm moderate, 3-lax

15 Type of lamina tip of middle involucral bracts: 1- oblong- ovate; 2- linear; 3- oblong and recurved to behind

16 Middle involucral bracts indumentum: 1- tomentose- glandular or lanate- glandular, 2- \pm glabrous; 3- glandular

17 Shape of lamina tip of middle involucral bracts: 1- acute; 2- obtuse

18 Shape of lamina of inner involucral bracts: 1- oblanceolate and convex; , ovate and convex; 2- linear; 3- long and recurved to behind

19 Inner involucral bracts indumentums: 1-tomentose,tomentose-glandular; 2-glandular in part tomentose; 3-glandular; 4- lanate- glandular

20 Leaf margin: $1-$

21 Pappus hairs apical cell shape: 1 - acute to sub acute to ; 2- obtuse to sub obtuse; 3 -

22 Achenial papillae: 1- white duplex; 2-yellow/ orange duplex; 3-yellow/ orange multi cellular

23 Corolla lobes recurved: 1 - erect; 2 - recurved

24 Lateral stem: 1-present; 2- absent

25 Brown wish pigmentation in lamina/stereome gap of tip of Middle involucral bracts: (0) absent; (1) present.

26 Longitudinal plicate of phyllary: 1- present; 2- absent

27 Papuss bristles; 1 - plumose; 2 - smooth or \pm smooth

28 Innermost phyllaries length / outermost phyllaries length

29 Basal leaf width $(\mathrm{mm})$

30 Achene length ( $\mathrm{mm})$

31 Receptacle dimension ( $\mathrm{mm}$ )

32 Pappus length ( $\mathrm{mm}$ )

33 No. of flower per capitule (mm)

34 Resting bud width ( $\mathrm{mm}$ )

35 Corolla length $(\mathrm{mm})$

36 Involucres width (mm) 